\begin{tabular}{|l|l|}
\hline \multicolumn{3}{|c|}{ Access this article online } \\
\hline Quick Response Code: & $\begin{array}{l}\text { Website: } \\
\text { www.annalsafrmed.org }\end{array}$ \\
\hline & DOI: \\
\hline & P. \\
\hline
\end{tabular}

\title{
Oxidative stress in diabetic patients with retinopathy
}

\author{
Dipankar Kundu, Tridibeswar Mandal, Mausumi Nandi' ${ }^{1}$, Manish Osta ${ }^{2}$, \\ Ujjwal Bandyopadhyay², Debes Ray \\ Departments of Biochemistry, ${ }^{1}$ Physiology, and ${ }^{2}$ Pathology, Medical College, Kolkata, West Bengal, India
}

Correspondence to: Dr. Dipankar Kundu, Medical College, Kolkata - 700 037, West Bengal, India.

E-mail:drdipankar@yahoo.co.in

\begin{abstract}
Background: Diabetes mellitus (DM) is known to induce oxidative stress along with deranging various metabolisms; one of the late complications of diabetes mellitus is diabetic retinopathy, which is a leading cause of acquired blindness. Poor glycemic control and oxidative stress have been attributed to the development of complications like diabetic retinopathy. The aim of this study was to analyze and correlate oxidative stress marker, Malondialdehyde (MDA), and antioxidants (erythrocyte glutathione, vitamin $\mathrm{C}$ ) along with glycosylated hemoglobin $\left(\mathrm{HbA}_{1 \mathrm{c}}\right)$ and fasting blood sugar (FBS) in diabetic patients with and without retinopathy.

Materials and Methods: The study population comprised of 50 type 2 diabetics with retinopathy as Group 1 (G1) and 50 type 2 diabetics without retinopathy as Group 2 (G2) in the age group 40-70 years as patients, and 50 ageand gender-matched healthy individuals as controls, Group 3 (G3). FBS, $\mathrm{HbA}_{1 \mathrm{c}} \mathrm{MDA}$, glutathione in erythrocytes, and vitamin $\mathrm{C}$ were assayed. Results were analyzed using SPSS 11.0, Mann-Whitney U-test, and Pearson correlation coefficient.

Results: Mean FBS (mg/dl) were 194.04 488.52 (G1), $181.24 \pm 50.05$ (G2), and $92.20 \pm 9.19$ (G3) $(P<0.001)$. Mean values of MDA were $6.65 \pm 0.30(\mathrm{G} 1), 4.63 \pm 0.56(\mathrm{G} 2)$, and $3.90 \pm 0.34(\mathrm{G} 3)(P<0.001)$. The mean reduced glutathione (GSH) levels were (mg/g of Hb) $6.10 \pm 1.41(\mathrm{G} 1), 6.44 \pm 1.53(\mathrm{G} 2)$, and $13.09 \pm 2.49(\mathrm{G} 3)(P<0.001)$. The mean vitamin C levels (mg/dl) were $0.70 \pm 0.24$ (G1), $0.87 \pm 0.29$ (G2), and $1.25 \pm 0.27(\mathrm{G} 3)(P<0.001)$.

Conclusion: Estimation of $\mathrm{HbA}_{1 \mathrm{c}}$, MDA, GSH in erythrocytes, and vitamin $\mathrm{C}$ levels can contribute to determine the extent of oxidative stress in diabetes and help in effective control and prevention of the onset and progression of diabetic retinopathy.
\end{abstract}

Keywords: Diabetic retinopathy, glycosylated hemoglobin, malondialdehyde, reduced glutathione, vitamin C

\section{Résumé}

Contexte : Diabète sucré (DM) est connue pour induire le stress oxydatif ainsi que déranger les divers métabolismes; une des complications du diabète sucré fin est la rétinopathie diabétique, qui est des principales causes de cécité acquise. Mauvais équilibre glycémique et du stress oxydatif ont été attribués à l'apparition de complications comme la rétinopathie diabétique. Le but de cette étude était d'analyser et de corrélation entre les marqueurs de stress oxydatif, malondialdéhyde (MDA) et antioxydants (glutathion érythrocytaire, vitamine $C$ ) ainsi que de l'hémoglobine glycosylée (HbA1c) et la glycémie à jeun (FBS) chez les patients diabétiques, avec ou sans rétinopathie.

Matériaux et méthodes: la population étudiée se compose de 50 type 2 diabétiques avec rétinopathie dans le groupe 1 (G1) et 50 diabétiques de type 2 sans rétinopathie dans le groupe 2 (G2) dans le groupe d'âge 40-70 ans que les patients et 50 appariés selon l'âge et le sexe des individus sains comme témoins, groupe 3 (G3). FBS, HbA1C MDA, glutathion dans les érythrocytes et la vitamine C ont été dosés. Résultats ont été analysés à l'aide de SPSS 11.0, Mann - Whitney U-test et le coefficient de corrélation de Pearson.

Résultats : FBS moyenne (mg/dl) ont été194.04 \pm 48,52 (G1), $181.24 \pm 50.05$ (G2), et92.20 $\pm 9.19(\mathrm{G} 3)(P<0,001)$. Valeurs moyennes du MDA observées étaient 6,65 $\pm 0,30$ (G1), $4.63 \pm 0,56$ (G2) et 3,90 $\pm 0,34(\mathrm{G} 3)(P<0,001)$. 
La moyenne a réduit les niveaux de glutathion (GSH) étaient (mg/g d'Hb) $6.10 \pm 1,41$ (G1), 6,44 $\pm 1,53$ (G2) et \pm $13,092,49(\mathrm{G} 3)() P<0,001)$. Les niveaux moyen en vitamine $C(\mathrm{mg} / \mathrm{dl})$ étaient $0,70 \pm 0,24(\mathrm{G} 1), 0.87 \pm 0,29(\mathrm{G} 2)$ et $1,25 \pm 0,27(\mathrm{G} 3)(P<0,001)$.

Conclusion : Estimation de $\mathrm{HbA1C}, \mathrm{MDA}, \mathrm{BA}$ dans les érythrocytes et les niveaux de vitamine $\mathrm{C}$ peut contribuer à déterminer l'étendue du stress oxydatif dans le diabète et l'aide dans le contrôle effectif et la prévention de l'apparition et la progression de la rétinopathie diabétique.

Mots-clés : Rétinopathie diabétique,hémoglobine glycosylée, malondialdéhydele glutathion, la vitamine $\mathrm{C}$ réduit

\section{Page|42 Introduction}

Multisystem effects of diabetes mellitus (DM) such as retinopathy, nephropathy, neuropathy, and cardiovascular diseases are important public health concerns. Diabetic retinopathy (DR) is one of the leading causes of blindness in the world. ${ }^{[1]}$ Using new surgical and medical techniques, the incidence of blindness can be reduced up to $90 \%$. $\mathrm{DR}$ is one of the leading causes of decrease in visual acuity, which is associated with maculopathy or proliferative complications of it other than cataract. Chronic hyperglycemia and its associated nonenzymatic glycation play an important role in the development of microangiopathy. There are a series of risk factors related to the development and progression of DR such as duration of DM, poor glycemic control, and oxidative stress. ${ }^{[2]}$ The measurement of glycosylated hemoglobin $\left(\mathrm{HbA}_{1 \mathrm{c}}\right)$ is used in the long-term monitoring of $\mathrm{DM}$. The level of $\mathrm{HbA}_{1 \mathrm{c}}$ has been widely accepted as an indicator of mean daily blood glucose levels (glycemic index) over the preceding 6-8 weeks. Intensive glycemic control as measured by serum $\mathrm{HbA}_{1 \mathrm{c}}$ levels has been demonstrated in randomized trials to reduce diabetic complications, especially microvascular disease. This may be due to the fact that $\mathrm{HbA}_{1 \mathrm{c}}$ has special affinity for oxygen, thereby causing tissue anoxia, and plays a role in causation of micro- and macroangiopathy. ${ }^{[2]}$

Retinopathy is related not only to hyperglycemia but also to the duration of DM. Oxidative stress has been implicated in the pathogenesis of DR. ${ }^{[3]}$ It has been hypothesized that hyperglycemia may damage the vascular endothelium and the retina by inducing the synthesis of oxidant reactive species. Free radicals are chemical species possessing an unpaired electron which are generally very reactive that may lead to increased lipid peroxidation and depletion of antioxidants, and thereby enhanced oxidative stress in subjects with type $2 \mathrm{DM}$. Recently, there has been a focus on DNA damage due to oxidative stress and the emphasis lies on sensitive biomarkers indicating them. Damage to DNA may induce cell death or mutation that could give rise, several cellular divisions later, to cancer. There is an increasing interest in using oxidative DNA lesions as in vivo biomarkers of oxidative stress. The aim of this study was to correlate between all these risk factors in diabetic patients with retinopathy, diabetic patients without retinopathy, and healthy controls.

\section{Materials and Methods}

The study was conducted after obtaining usual permission from the Ethical Committee, and consent from subjects and controls were taken before commencing the study. The study group consisted of a total of 150 individuals divided into three groups studied from 2011 to 2012. Fasting blood sugar (FBS) $>126 \mathrm{mg} / \mathrm{dl}$ was taken to be the criteria for diagnosis of diabetes as per the American Diabetes Association guidelines, 2012. ${ }^{[4]}$ Patients aged between 40 and 70 years, gender-matched in all the groups, were included in the study. All the diabetic patients enrolled in the study(Group 1 and 2) were screened for the presence of retinopathy by direct and indirect ophthalmoscopy and fundus photography who attended the outpatient and inpatient department at Regional Institute of Ophthalmology, Medical College, Kolkata. History and physical data were obtained from both groups of cases and controls. Systolic blood pressure and diastolic blood pressure were measured for all the subjects. Fifty cases of type 2 diabetes with retinopathy were included in Group 1. Fifty diabetic subjects without retinopathy changes based on fundoscopic examination were included in Group 2 and 50 age- and gendermatched normal healthy individuals were included in Group 3. In Group 1, nondiabetic patients presenting with retinopathy and any subject with a recent history of fever, infection, and chronic illness such as cancer, chronic obstructive lung disorders, cardiac diseases, stroke, gestational DM, and complications related to diabetes such as ulcers, neuropathy, and nephropathy which are known to affect oxidative stress parameters were excluded from the study. Any subject receiving antioxidant therapies were also excluded from the study. In Group 2, individuals with type $2 \mathrm{DM}$ with diabetic retinopathy or other complications and on antioxidant drugs were excluded from the study. 
After obtaining written consent, with $8 \mathrm{~h}$ of fasting, $10 \mathrm{ml}$ of venous blood was collected from the median cubital vein under complete aseptic precautions from all the subjects. First sample was collected in the tube containing fluoride and was used for the estimation of fasting blood glucose by glucose oxidase enzymatic method using the Diasys kit. ${ }^{[5]}$ Second sample was collected in the tube containing Ethylene Diamine Tetraacetic Acid(EDTA) for the estimation of $\mathrm{HbA}_{1 \mathrm{c}}$ by immunoinhibition method International Federation of Clinical Chemistry and Laboratory Medicine,(IFCC) using the Diasys kit. ${ }^{[6]}$ Blood sample from the anticoagulant (EDTA)-containing vacutainer was centrifuged at $3000 \mathrm{rpm}$ for $10 \mathrm{~min}$; supernatant plasma was used for ascorbic acid estimation by nonenzymatic method, using 2, 4-dinitrophenyl hydrazine (DNPH). ${ }^{[7]}$ The buffy coat was discarded. The packed cells were suspended in equal volume of cold phosphate buffer saline and recentrifuged. The supernatant was discarded. The washing of packed cells was repeated twice; the packed cells were used for analysis of reduced glutathione (GSH) estimation in RBC by colorimetric method using 5,5'-dithiobis 2-nitrobenzoic acid (DTNB) as chromogen. ${ }^{[8]}$ Determination of malondialdehyde (MDA) was carried out by Thio-barbituric acid reacting substances, TBARS method. ${ }^{[9]}$ These parameters were analyzed in the Central Clinical Biochemistry Laboratory, Medical College, Kolkata.

\section{Statistical analysis}

The statistical software SPSS 11.0, International Business Machines Corporation, Systat 8.0, and Mann-Whitney $U$-test were used for the analysis of the data, and Microsoft Word and Excel were used to generate tables. Correlation of parameters was carried out using Pearson correlation coefficient. The percentage of significance was obtained on the basis of $R$ - and $P$-values.

\section{Results}

The age of the patients was between 40 and 70 years for all the three groups. The mean age in diabetic patients with retinopathy was $58.56 \pm 9.09$ years, in diabetic patients without retinopathy $56.20 \pm 9.89$ years, and in controls $51.79 \pm 10.12$ years. In diabetic patients with retinopathy, the number of men was 36 and women was 14. Among the diabetic patients without retinopathy, the number of men was 39 and women was 11 . The control group included 34 men and 16 women. The cases and controls were gender-matched. The mean duration of DM in diabetic patients with retinopathy as indicated by their history was $15.4 \pm 1.06$ years, and in diabetic patients without retinopathy, it was $4.84 \pm 1.15$ years.
There was a significant increase in the $\mathrm{HbA}_{1 \mathrm{c}}$ levels in diabetic patients with retinopathy compared to that in diabetic patients without retinopathy $(P<0.001)$. Mean values of FBS, $\mathrm{HbA}_{1 \mathrm{c}}$, and MDA, and antioxidant parameters (glutathione and vitamin $\mathrm{C}$ ) in cases and controls are depicted in Tables 1 and 2, respectively. Table 3 depicts the age distribution in Group 1, Group 2, and Group 3. Duration of diabetes in Group 1 and Group 2 with FBS levels is depicted in Tables 4 and 5, respectively. Table 6 depicts the blood pressure in all the groups. Systolic blood pressure has significance in Group 1 $(P<0.01)$. Table 7 depicts the values of correlation of $\mathrm{HbA}_{1 c}(\%)$ with the indices of oxidative stress. Correlation graphs of FBS versus MDA and FBS versus vitamin $\mathrm{C}$ are depicted in Figures 1 and 2, respectively.

Table 1: Fasting blood sugar and $\mathrm{HbA}_{1 \mathrm{c}}$ in cases and controls

\begin{tabular}{|c|c|c|}
\hline \multirow[t]{2}{*}{ Groups } & \multicolumn{2}{|c|}{ Mean \pm SD } \\
\hline & FBS (mg/dl) & $\mathrm{HbA}_{1 \mathrm{c}}(\%)$ \\
\hline $\begin{array}{l}\text { Group } 1 \text { - Type } 2 \text { diabetes } \\
\text { with retinopathy }\end{array}$ & $194.04 \pm 48.52^{*}$ & $7.94 \pm 1.02^{* \text { * }}$ \\
\hline $\begin{array}{l}\text { Group } 2 \text { - Type } 2 \text { diabetes } \\
\text { without retinopathy }\end{array}$ & $181.24 \pm 50.05^{\star *}$ & $7.18 \pm 0.97^{\star \star}$ \\
\hline Group 3 - Control & $92.20 \pm 9.19$ & $5.49 \pm 0.49$ \\
\hline
\end{tabular}

* 1 versus 3 - Highly significant: $P<0.001$, ** 2 versus 3 Highly significant: $P<0.001,{ }^{*} 1$ versus 2 - Significant: $P<0.01$. $\mathrm{HbA}_{1 \mathrm{c}}=$ Glycosylated hemoglobin

Table 2: Oxidative stress marker and antioxidants in cases and controls

\begin{tabular}{lccc}
\hline Groups (mg/dl) & \multicolumn{3}{c}{ Mean \pm SD } \\
\cline { 2 - 4 } & $\begin{array}{c}\text { MDA } \\
(\mathrm{nmol} / \mathrm{ml})\end{array}$ & $\begin{array}{c}\text { Glutathione } \\
(\mathrm{mg} / \mathrm{g} \text { of Hb) }\end{array}$ & Vitamin C \\
\hline $\begin{array}{l}\text { Group 1 (with } \\
\text { retinopathy) }\end{array}$ & $6.65 \pm 0.30$ & $6.10 \pm 1.41$ & $0.70 \pm 0.24$ \\
Group 2 (without & $6.44 \pm 1.53$ & $0.87 \pm 0.29$ & \\
retinopathy) & & & \\
4.63 \pm 0.56 & & & \\
Group 3 - Control & $3.90 \pm 0.34$ & $13.09 \pm 2.49$ & $1.25 \pm 0.27$ \\
3 versus 2 & $P<0.001$ & $P<0.001$ & $P<0.001$ \\
3 versus 1 & $P<0.001$ & $P<0.001$ & $P<0.001$ \\
2 versus 1 & $P<0.001$ & $P<0.001$ & $P<0.001$ \\
\hline
\end{tabular}

Highly significant: $P<0.001$. MDA=Malondialdehyde, $\mathrm{SD}=\mathrm{Standard}$ deviation

Table 3: Age distribution in Group 1, Group 2 and Group 3

\begin{tabular}{lccc}
\hline Age in years & $\begin{array}{c}\text { Group 1 } \\
(n=50)\end{array}$ & $\begin{array}{c}\text { Group 2 } \\
(n=50)\end{array}$ & $\begin{array}{c}\text { Group 3 } \\
(n=50)\end{array}$ \\
\hline $40-44$ & 3 & 2 & 5 \\
$45-49$ & 4 & 6 & 9 \\
$50-54$ & 9 & 12 & 16 \\
$55-59$ & 13 & 16 & 15 \\
$60-64$ & 12 & 9 & 3 \\
$65-69$ & 9 & 5 & 2 \\
Mean \pm SD & $58.56 \pm 9.09$ & $56.20 \pm 9.89$ & $51.79 \pm 10.12$ \\
\hline
\end{tabular}

Inference: Samples are age matched with $P<0.612$ 


\begin{tabular}{l}
\hline \multicolumn{3}{l}{$\begin{array}{l}\text { Table 4: Duration of diabetes with retinopathy in } \\
\text { Group } 1 \text { and fasting blood sugar levels }\end{array}$} \\
\begin{tabular}{lcc}
\hline $\begin{array}{l}\text { Duration of } \\
\text { diabetes (years) }\end{array}$ & Group $1(n=50)$ & FBS $(\mathrm{mg} / \mathrm{dl})$ \\
\hline$<5$ & 1 & 145 \\
$5-10$ & 9 & $153 \pm 6.02$ \\
$11-15$ & 18 & $159 \pm 11.21$ \\
$>15$ & 22 & $207.34 \pm 35.22$ \\
\hline$P<0.001$ (highly significant). FBS=Fasting blood sugar
\end{tabular}
\end{tabular}

Page | 44

Table 5: Duration of diabetes without retinopathy in Group 2 and fasting blood sugar levels

\begin{tabular}{lcc}
\hline $\begin{array}{l}\text { Duration of } \\
\text { diabetes }\end{array}$ & Group $2(n=50)$ & FBS $(\mathrm{mg} / \mathrm{dl})$ \\
\hline$<5$ years & 27 & $137 \pm 5.81$ \\
$5-10$ years & 11 & $147.26 \pm 9.02$ \\
$11-15$ & 5 & $189 \pm 42.29$ \\
$>15$ years & 7 & $201 \pm 30.05$ \\
\hline$P<0.001$ (highly significant). FBS=Fasting blood sugar
\end{tabular}

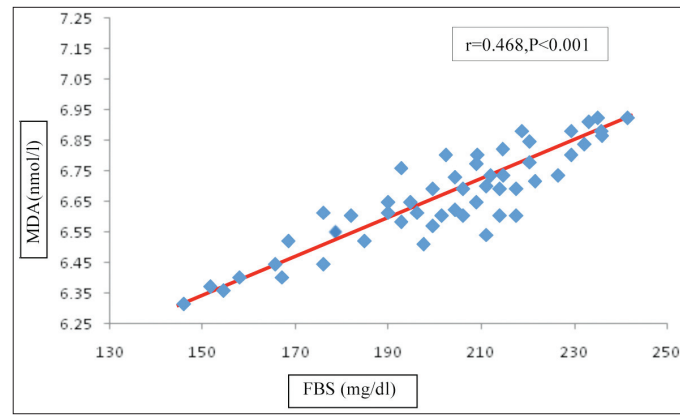

Figure 1: Correlation graph between fasting blood sugar and malondialdehyde in type 2 diabetes with retinopathy

\section{Discussion}

DR is one of the microvascular complications of DM. It is one of the leading causes of acquired blindness due to microangiopathy affecting the retinal arterioles, capillaries, and venules. ${ }^{[10]}$ Damage is caused by both microvascular leakage and microvascular occlusion. A series of risk factors have been related to the development and progression of retinopathy in diabetic patients. In this study, the number of cases in DR group was found to be more between the age group of 56-70 years (56\%). It was observed that DR was found to be higher in men compared with women. Several studies revealed that DR is more prevalent among men compared with women. ${ }^{[1-13]}$ Female preponderance over males has been found in Joslin Clinic patients.

The mean duration of DM in diabetic patients with retinopathy was $15.4 \pm 1.06$ years and in diabetic patients without retinopathy, it was $4.84 \pm 1.15$ years. The duration of DM was significantly higher in diabetic patients with retinopathy compared with that in diabetic patients without retinopathy, as

\begin{tabular}{lllll}
\hline \multicolumn{5}{l}{ Table 6: Blood pressure in all the groups } \\
\hline Parameter & Group 1 & Group 2 & Group 3 & $P$ value \\
\hline $\begin{array}{l}\text { Systolic blood } \\
\text { pressure }\end{array}$ & $142 \pm 18.2$ & $139 \pm 17.3$ & $109 \pm 11.5$ & $P<0.01$ \\
$\begin{array}{l}\text { (mmHg) } \\
\text { Diastolic }\end{array}$ & $81.9 \pm 9.93$ & $82.2 \pm 9.84$ & $79 \pm 4.01$ & $\begin{array}{c}\text { Not } \\
\text { blood }\end{array}$ \\
$\begin{array}{l}\text { pressure } \\
\text { (mmH) }\end{array}$ & & & & \\
\hline
\end{tabular}

Table 7: Correlation of $\mathrm{HbA}_{1 \mathrm{c}}(\%)$ with the indices of oxidative stress

\begin{tabular}{lcccc}
\hline Parameter & Value & Group 1 & Group 2 & Group 3 \\
\hline MDA & $R$ & 0.50 & 0.58 & 0.11 \\
& $P$ & $0.05^{\star}$ & 0.43 & 0.73 \\
Glutathione & $R$ & 0.95 & -0.32 & -0.34 \\
& $P$ & 0.76 & 0.12 & 0.09 \\
Vitamin C & $R$ & 0.08 & 0.17 & 0.04 \\
& $P$ & 0.69 & 0.43 & 0.87 \\
\hline
\end{tabular}

${ }^{\star} P<0.05$ (significant). $\mathrm{HbA}_{10}=$ Glycosylated hemoglobin, MDA=Malondialdehyde

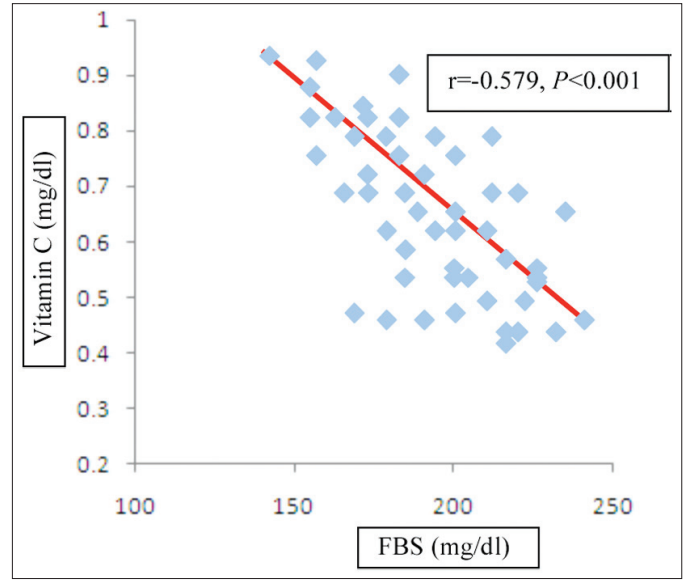

Figure 2: Correlation graph between fasting blood sugar and vitamin $\mathrm{C}$ in type 2 diabetes with retinopathy

shown in our results. Our findings are in agreement with previous studies ${ }^{[10,13]}$ which proposed that the duration of DM is probably the strongest predictor for the development of retinopathy. Studies have also shown that for every 5 -year increase in the duration of DM, the risk of DR increases by 1.89 times. $^{[10]}$ The above findings show that the duration of DM is one of the important risk factors in the development of DR.

This study revealed there was a significant increase in the FBS levels and $\mathrm{HbA}_{1 c}$ levels in diabetic patients with retinopathy and in diabetic patients without retinopathy, when compared with that in the controls. Similar findings of increased FBS and increased $\mathrm{HbA}_{1 c}$ are seen in the previous studies. ${ }^{[14]}$

In our study, we found increased lipid peroxidation in terms of MDA in diabetics compared with controls 
and this increase was more in diabetic retinopathy. Gallau et al. ${ }^{[15]}$ demonstrated that lipid peroxides (MDA) were higher in diabetics with retinopathy compared with those with diabetics without retinopathy. Yildiz et al. ${ }^{[16]}$ also identified higher MDA levels in the group with retinopathy, compared with those in the group without retinopathy. There are a few biochemical mechanisms that explain the reason for this rise. The increase in the blood free fatty acid levels depending on the degree of lipolysis results in an increase in MDA production. Increased MDA levels of diabetic individuals may take origin from the peroxidative damage of the membrane lipids. Jennings et al. ${ }^{[17]}$ have shown that increased free radical activity leads to an increase in thrombotic tendency and a reduction in prostacyclin stimulating factors depending on the increase in thrombocyte reactivity in diabetics. Since lipid peroxides play a major role in the formation of vascular tissue damage, it is suggested that an increase in MDA in diabetes can be effective in the pathogenesis of diabetic angiopathy. It has been indicated that an increase in free fatty acids along with lack of insulin contributes to high MDA levels.

In our present study, there was a statistically significant decrease in the GSH and in vitamin C levels in diabetic retinopathy and diabetic without retinopathy groups, when compared with the control group. There was a statistically significant decrease in vitamin $\mathrm{C}$ levels in diabetic retinopathy when compared to diabetic without retinopathy group $(P<0.05)$. We found that in our study, there was no statistically significant correlation between GSH and other parameters in all three groups, but there was statistically significant correlation between vitamin C and FBS levels in the control group $(P<0.05)$.

Our findings agree with the previous study which included 25 patients with Proliferative Diabetic Retinopathy,PDR (1), 25 patients with Non-Proliferative Diabetic Retinopathy,NPDR (2), and 25 nondiabetic control to know the severity of DR, by measuring serum copper, zinc $(\mathrm{Zn})$, nitric oxide, glutathione, advanced oxidation protein products (AOPP) levels, and superoxide dismutase (SOD). The study showed no difference in levels of SOD and $\mathrm{Zn}$ between the groups; statistically significant differences were observed for GSH, $\mathrm{NO}$, and $\mathrm{Cu}$ levels when compared to the control group. AOPP levels were statistically increased in group I when compared to the control group. The study suggested that hyperglycemia in DM is associated with accelerated nonenzymatic glycation and oxidative stress. ${ }^{[18]}$

Similar studies have shown statistically significant decrease in GSH levels in DR and diabetic without retinopathy groups, when compared with the control group. ${ }^{[19,20]} \mathrm{A}$ previous study has also shown statistically significant decrease in vitamin C levels in DR and diabetic without retinopathy groups, when compared with the control group. ${ }^{[21]}$

A previous study conducted included 33 patients with type 1 diabetes, 27 patients with type 2 diabetes with $\mathrm{DR}(\mathrm{II})$, and 32 nondiabetic controls, by measuring MDA, conjugated diene (CD), AOPP and 8-hydroxydeoxyguanosine (8-OHdg) levels, and SOD. The study showed significant increase in MDA, 8-OHdg, CD levels, and AOPP levels in DR and DM when compared to controls. It also showed significant increase in MDA, 8-OHdg, CD levels, and AOPP levels in DR when compared to that in DM. The study suggested that oxidative stress is an important risk factor in the development of retinopathy. The levels and the type of serum oxidative stress by-products will favor in predicting the amount of retinopathy. ${ }^{[22]}$

A previous study investigated for a new sensitive biomarker of oxidative DNA damage in vivo. Oxidative stress relates to the pathogenesis of diabetic microvascular complications like DR. So they studied urinary levels of 8-OHdg in patients with type 2 diabetes and found it to be higher along with a positive correlation with $\mathrm{HbA}_{1 c}$ values. Hence they concluded that 8-OHdg is a sensitive biomarker for early diagnosis and treatment of patients with DR. ${ }^{[23]}$

These observations support the suggestion that chronic hyperglycemia can influence the generation of free radicals, which may lead ultimately to increased lipid peroxidation and depletion of antioxidants and thereby enhanced oxidative stress in subjects with type 2 DM. Studies have suggested that increased capillary permeability, microangiopathy, and retinal ischemia are probably due to the combined effects of various risk factors.

Several limitations are present in this study. First, the presence of DR was studied in detail, whereas nephropathy, neuropathy, and cardiovascular complications were only estimated clinically. Second, the study's cross-sectional nature prevents conclusions concerning the predictive value of advanced glycation end-products (AGEs) for complication development. Third, this study is a cross-sectional study compromising a small group; therefore, the directionality of associations cannot be clearly established. Last, the findings for DR is based wholly on ophthalmoscopy (direct/indirect) findings and without the benefit of fluorescein angiography (FA). So, large-scale clinical trials to establish the 
role of oxidative stress in the pathogenesis and progression of DR are worth undertaking.

\section{Conclusion}

GSH and vitamin C levels were significantly altered in DM with complications and without complications when compared to that in normal individuals, suggesting the role of uncontrolled hyperglycemia as a cause and consequence of oxidative stress. With poor glycemic control, oxidative stress (measured by increased MDA levels) in diabetes can cause profound damage to the vital organs in the body. Hence, determination of GSH in erythrocytes and vitamin $\mathrm{C}$ levels can contribute to know the extent of oxidative stress in diabetes and help in effective control and prevention of the onset and progression of complications like DR.

\section{Acknowledgments}

We thank Mr. Arup Ratan Chowdhury and Mr. Subir Mondal, technical staff, for their active participation in our study: Special thanks to the management of Medical College, Kolkata, for their active participation.

\section{References}

1. Correa ZM, Freitas AM, Marcon IM. Risk factors related to the severity of diabetic retinopathy. Arquivos Brasileiros De Oftalmologia 2003;66:739-43.

2. Dworacka M, Winiarska H, Kuczynski S. The association between glycoxidation and chronic or acute hyperglycemia in type 2 diabetic patients with retinopathy. Int ] Diabetes Metab 2006;14:27-31.

3. Bertelsen M, Anggård EE, Carrier M]. Oxidative stress impairs insulin internalization in endothelial cells in vitro. Diabetologia 2001;44:605-13.

4. Riethof M, Flavin PL, Lindvall B, Michels R, O'Connor P, Redmon B, et al. Health care guideline. Diagnosis and Management of Type 2 Diabetes Mellitus in Adults. Bloomington, USA: Institute for Clinical Systems Improvement; 2012. p. 1-141.

5. Sacks DB. Carbohydrates. In: Burtis CA, Ashwood ER, Bruns DE, editors. Tietz Textbook of Clinical Chemistry and Molecular Diagnostics. St. Louis: Elsevier Saunders; 2006. p. 837-902.

6. Hanas R, John G, International HbA Consensus Committee. 2010 consensus statement on the worldwide standardization of the hemoglobin $A_{1 c}$ measurement. Pediatr Diabetes 2010;11:209-11.

7. Shenkin A, Baines M, Gorden S, Lyon TD. Vitamins and trace elements. In: Burtis CA, Ashwood ER, Bruns DE, editors. Tietz Text book of Clinical Chemistry and Molecular Diagnostics. St. Louis: Elsevier Saunders; 2006. p. 1105-7.
8. Panteghini M, Bais R, Wouter W, Solinge V. Enzymes. In: Burtis CA, Ashwood ER, Bruns DA, editors. Tietz Text Book of Clinical Chemistry and Molecular Diagnostics. $4^{\text {th }}$ ed. New Delhi: Elsevier Co.; 2006. p. 631-5.

9. Premanand R, Kumar S, Mohan A. Study of thiobarbituric reactive substances and total reduced glutathione as indices of oxidative stress in chronic smokers with and without chronic obstructive pulmonary disease. Indian ] Chest Dis Allied Sci 2007;49:9-12.

10. Rema M, Pradeepa R. Diabetic retinopathy: An Indian perspective. Indian ] Med Res 2007;125:297-310.

11. Rema M, Premkumar S, Anitha B, Deepa R, Pradeepa R, Mohan V. Prevalence of diabetic retinopathy in urban India: The Chennai Urban Rural Epidemiology Study (CURES) eye study, I. Invest Ophthalmol Vis Sci 2005;46:2328-33.

12. Harris MI, Klein R, Welborn TA, Knuiman MW. Onset of NIDDM occurs at least 4-7 yr before clinical diagnosis. Diabetes Care 1992;15:815-9.

13. Dandona L, Dandona R, Naduvilath T], McCarty CA, Rao GN. Population based assessment of diabetic retinopathy in an urban population in southern India. $\mathrm{Br}$ ] Ophthalmol 1999;83:937-40.

14. Al-Shammari FK, Al-Meraghi O, Nasif A, Al-Otaibi S. The prevalence of diabetic retinopathy and associated risk factors in type 2 diabetes mellitus in $\mathrm{Al}-\mathrm{Naeem}$ area (Kuwait). Middle East ] Am Board Fam Med 2005;3:1-8.

15. Gallou G, Ruelland A, Legras B, Maugendre D, Allannic H, Cloarec L. Plasma malondialdehyde in type 1 and type 2 diabetic patients. Clin Chim Acta 1993;214:227-34.

16. Yildiz AT, Yuksei K, Aytac A, Nuriye M, Naime C, GultenT. Alterations of erythrocyte and plasma lipid peroxides as well as antioxidant mechanism in patients with type 2 diabetes mellitus. Turkish Journal of Medical Sciences, 1996;28:143-8.

17. Jennings PE, McLaren M, Scott NA, Saniabadi AR, Belch ]J.The relationship of oxidative stress to thrombotic tendency in type 1 diabetic patients with retinopathy. Diabet Med 1991;8:860-5.

18. Yildirim Z, Uçgun NI, Kiliç N, Gürsel E, Sepici-Dinçel A. Antioxidant enzymes and diabetic retinopathy. Ann N Y Acad Sci 2007;1100:199-206.

19. Abou-Seif MA, Youssef AA. Evaluation of some biochemical changes in diabetic patients. Clin Chim Acta 2004;346:161-70.

20. Gürler B, Vural H, Yilmaz N, Oguz H, Satici A, Aksoy N. The role of oxidative stress in diabetic retinopathy. Eye (Lond) 2000;14:730-5.

21. Kumari S, Panda S, Mangaraj M. Plasma MDA and antioxidant vitamins in diabetic retinopathy. Indian ] Clin Biochem 2008;23:158-62.

22. Pan HZ, Zhang H, Chang D, Li H, Sui H. The change of oxidative stress products in diabetes mellitus and diabetic retinopathy. Br ] Ophthalmol 2008;92:548-51.

23. Dong QY, Cui Y, Chen L, Song J, Sun L. Urinary 8-hydroxydeoxyguanosine levels in diabetic retinopathy patients. Eur ] Ophthalmol 2008;18:94-8.

Cite this article as: Kundu D, Mandal T, Nandi M, Osta M, Bandyopadhyay U, Ray D. Oxidative stress in diabetic patients with retinopathy. Ann Afr Med 2014;13:41-6.

Source of Support: RIO, Medical College, Kolkata, West Bengal, India. Conflict of Interest: None declared. 